\title{
Reflections on 20 years of RNA
}

\section{DAVID E. DRAPER}

Department of Chemistry, Johns Hopkins University, Baltimore, Maryland 21218, USA

My introduction to the RNA world started approximately 20 years before the 1994 founding of this journal; a few remarks on how I happened to take up RNA as a research theme during that time will serve as background to the excitement and promise for RNA studies that I sensed ca. 1994. As an undergraduate biochemistry major I had enjoyed enzymology and became intrigued by the ribosome, but thought its functions too complex to dissect with the tools then available and looked for something more approachable to study. In graduate school, I chose for my first student journal club presentation two papers that had just appeared in Biochemistry (1972), the now classic work on tRNA folding from Crothers's lab. Every student of RNA folding should read (and re-read) them and the papers that followed through 1976, as they outlined major themes still present in the RNA folding field: hierarchical folding of secondary and tertiary structure; the prevalence of misfolded structures; the strong stabilizing effects of salt, especially $\mathrm{Mg}^{2+}$. Here was a molecule that tied itself into an apparently compact, stable, and specific tertiary structure, even though its ludicrous amount of negative charge and limited set of "side chains" should have rendered it unfit for anything but information retrieval. My interest in the problem only grew as the $\mathrm{tRNA}^{\text {phe }}$ crystal structures approached atomic resolution over the next few years; the way base stacking and hydrogen bonding combined to enforce the shape of the molecule seemed to me both bizarre and elegant. (I still step through the tertiary interactions of new RNA crystal structures with pretty much the same sense.)

So I became hooked by what came to be called the "RNA folding problem." It seemed very unlikely that tRNA was a one-off, that nature would have used the shape of an RNA to solve a functional problem only once, but where else to look? In 1980, when setting up my own lab, there were strong hints that the ribosomal RNA might not be a passive bystander to protein synthesis, and suggestions from several quarters that some r-proteins recognized limited, conserved domains of secondary structure. Could r-proteins be used to identify small-ish RNA domains with well-defined tertiary structures? Indeed they could, not only in rRNAs but also in

\footnotetext{
Corresponding author: draper@jhu.edu

Article and publication date are at http://www.rnajournal.org/cgi/doi/ 10.1261/rna.050930.115. Freely available online through the RNA Open Access option.
}

the mRNAs of some r-protein operons. Readers of this journal will know the story of ribozymes, developing in the same decade, which opened up a new class of RNAs whose function depended on tertiary structure. Which brings us to the founding of RNA (the journal) in 1994, and the comingof-age of RNA (broadly defined) as a respectable field of study. Important from my perspective were the realizations that the questions initially posed in the 1970s about tRNA folding energetics were applicable to an expanding universe of functional RNAs, and that answers would require creative and sustained efforts. It looked like the next 20 years would be great scientific fun, and indeed they have been. Each person reflecting on the past two decades will have a different list of highlights; mine has to include the remarkable crystal structures of ribosomes; the discovery that bacteria have been carrying out SELEX under our noses, passing around ligand-recognition units to make into riboswitches (RNA can specifically recognize lysine? who knew); and single molecule methods that tug the ends of an RNA apart, watch fluctuations in the structure of a partially folded RNA, or follow tRNAs as they come and go on the ribosome.

Where do physical studies of RNA go from here? Most of the outstanding questions are fundamentally the same ones that emerged in the first studies of tRNA (see above), but now asked of a much wider range of structures, at higher resolution, and with more sophisticated tools. One broad class of questions concerns dynamics. Dynamics are integral to function: Many RNAs must unfold and re-fold to carry out their tasks, or select between alternative folding pathways. Crystal structures and two-state folding models are only the starting points for approaching these problems. Riboswitches are a fine example of the challenge. A first approximation of riboswitch mechanism is an RNA that folds into two alternative secondary structures, one bound to ligand, with consequences for either translation or transcription. But there remains the really interesting questions of how the RNA starts to fold as it emerges from the polymerase, how the presence or absence of ligand directs folding by one path over another, and how it is that alternative structures modulate translation or transcription. Starts have been made in sorting out these

(C) 2015 Draper This article, published in RNA, is available under a Creative Commons License (Attribution-NonCommercial 4.0 International), as described at http://creativecommons.org/licenses/by-nc/4.0/. 
kinds of problems by (for example) NMR, SAXS, and single molecule methods, but it will require considerable ingenuity to probe these kinds of questions more deeply.

It has usually paid to keep an eye on developments in the parallel universe of protein folding, which has (for instance) also been confronting the problem of domains that fold and unfold in the course of their function. But RNA presents the additional challenge of its very high charge density and corresponding entourage of counterions. Computational methods for estimating the energetics of long-range phosphate-ion interactions have been available for some time, but moderate-range interactions (one or two intervening water molecules) are very difficult to probe experimentally or reproduce accurately in silico. Remarkable progress is being made in bringing molecular dynamics simulations up to the task, but experimental benchmarks by which to judge computational results remain sparse.
I'll pose a last area of inquiry as an anthropomorphic question, What does it feel like to be an RNA inside of a cell? That is, how does RNA function in the context of cellular solvent environments? Conditions that are convenient for in vitro assays tend to differ from those found in vivo: Effective ion concentrations (i.e., ion activities) are sometimes far from physiological, cells may contain high concentrations of small neutral molecules (osmolytes), and overcrowding of macromolecules doesn't allow larger RNAs much room to maneuver in vivo (the excluded volume effect). RNAs are of course highly sensitive to salt concentrations, and available experiments suggest RNA stability is affected significantly by osmolytes and by crowding. We can hope that the extrapolations from in vitro to in vivo will be straightforward, but we don't have enough information yet to know whether this outcome is likely. The bet worth making, though, is that RNA will have many more surprises for us in the next 20 years. 

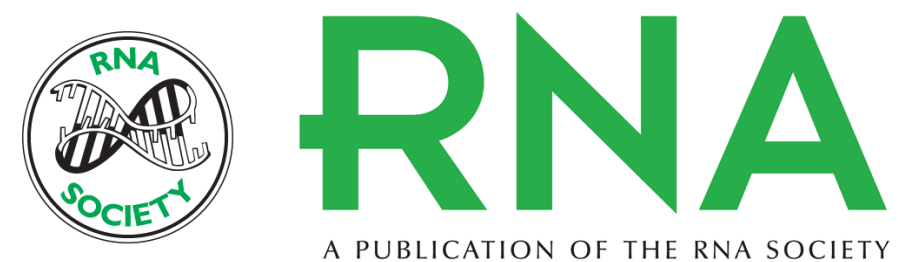

A PUBLICATION OF THE RNA SOCIETY

\section{Reflections on 20 years of RNA}

David E. Draper

RNA 2015 21: 601-602

Open Access Freely available online through the RNA Open Access option.

Creative This article, published in $R N A$, is available under a Creative Commons License Commons (Attribution-NonCommercial 4.0 International), as described at License http://creativecommons.org/licenses/by-nc/4.0/.

Email Alerting Receive free email alerts when new articles cite this article - sign up in the box at the Service top right corner of the article or click here. 